\title{
Stakeholder identification and analysis for adaptive governance in the Kovdozersky Model Forest, Russian Federation
}

\author{
by Marine Elbakidze ${ }^{1,2}$, Per Angelstam² and Robert Axelsson ${ }^{2}$
}

\begin{abstract}
The Model Forest is a concept developed to facilitate implementation of sustainable forest management (SFM). The key functions of a Model Forest are to develop innovations and test new ideas related to SFM, driven by the needs, interests and challenges of Model Forest stakeholders and local communities. Russia is an important global actor when it comes to the boreal forest biome and forestry, but also has several challenges related to development of adaptive governance and the introduction of SFM. The purpose of this study is to identify landscape stakeholders-their values, needs and interests-in order to develop and adapt the governance of forest landscapes in the Kovdozersky Model Forest. The location of the Kovdozersky Model Forest in the Barents region presents opportunities for learning between Nordic countries and Russia.
\end{abstract}

Key words: sustainable forest management, landscape, Barents region, Murmansk oblast, collaboration, social learning, integrated spatial planning, rural development

\section{RÉSUMÉ}

La Forêt Modèle est un concept qui a été élaboré pour faciliter la mise en ouvre de l’aménagement durable des forêts (ADF). Les principales fonctions d'une Forêt Modèle consistent à trouver des solutions novatrices et à mettre à lessai de nouvelles idées relatives à l'ADF, tout en tenant compte des besoins, des intérêts et des défis des intervenants des Forêts Modèles et des collectivités locales. La Russie est un acteur mondial important pour ce qui est du biome de la forêt boréale et de la foresterie, mais elle connaît également plusieurs difficultés concernant lélaboration d'une gouvernance adaptative et la mise en œuvre de l'ADF. Cette étude vise à identifier les intervenants des paysages et leurs valeurs, leurs besoins et leurs intérêts en vue délaborer une gouvernance adaptative des paysages forestiers dans la Forêt Modèle de Kovdozersky. L’emplacement de la Forêt Modèle Kovdozersky dans la région de Barents présente des occasions d’apprentissage entre les pays nordiques et en Russie.

Mots clés : aménagement durable des forêts, paysages, région de Barents, oblast de Murmansk, collaboration, apprentissage social, aménagement intégré du territoire, développement rural

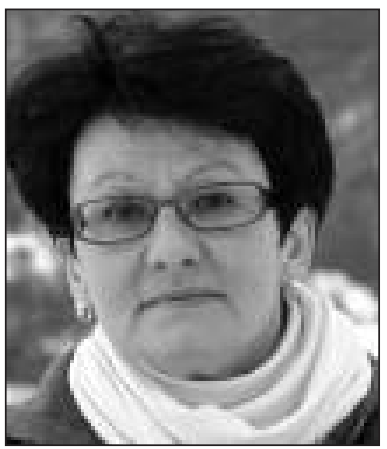

Marine Elbakidze

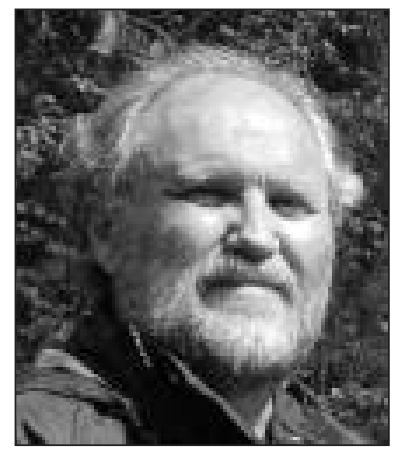

Per Angelstam

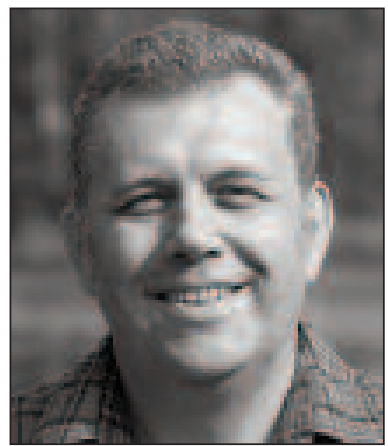

Robert Axelsson

\footnotetext{
${ }^{1}$ Corresponding author. E-mail: marine.elbakidze@slu.se

${ }^{2}$ Swedish University of Agricultural Sciences, Faculty of Forest Sciences, School for Forest Management, PO Box 43, SE-739 21 Skinnskatteberg, Sweden.
} 


\section{Introduction}

The concept of sustainable forest management (SFM) appeared as an answer to the gradual transition in societal norms, changing from a wood and monetary view only to the sustainable management of ecological, economic, social and cultural values (Shindler et al. 2003, Merlo and Croitoru 2005). SFM is defined as the stewardship and use of forests and forest lands in a way, and at a rate, that maintains their biodiversity, productivity, regeneration capacity, vitality and their potential to fulfil, now and in the future, relevant ecological, economic and social functions, at local, national, and global levels (Anon. 1995, 1998, 2001, 2007). Implementing SFM policies on the ground is highly dependent on the present status and development trends in an area, related to use of natural resources, biophysical conditions, landscape history, and the systems of government and governance (Lehtinen et al. 2004, Angelstam and Elbakidze 2010).

The development of collective action as a base for SFM implementation differs among places as well as over time. It can be initiated by local stakeholders bottom-up, or facilitated by external actors top-down. Different stakeholders may also have different interests and needs for taking part in collective action (Elbakidze et al. 2010). The literature on collective action in natural resource management has also recognized the importance of concerted efforts by policy entrepreneurs, facilitators, champions and other leaders in facilitating institutional development, i.e., rules and norms (Blomquist 1992, Thomas 2003, Nysten-Haarala 2009).

Model Forests represent one of several concepts developed to facilitate the sustainable development process towards sustainability on the ground (Shindler et al. 2003, Axelsson et al. 2008). The key functions of a Model Forest are to develop innovations and test new ideas related to SFM, driven by the needs, interests and problems of stakeholders (LaPierre 2002, IMFNS 2008). Thus, it is necessary to identify and analyze different stakeholders' use, interests and needs in terms of the spectrum of ecosystem services provided by forest landscapes. Results from such analyses should be reflected in the strategy and program of Model Forest activities in order to enhance the development of adaptive capacity among stakeholders at local and regional governance levels.

With a large proportion of intact forest (Potapov et al. 2008), the forests of the Russian Federation are important globally as a carbon sink (Shvidenko and Nilsson 2002), nationally as a source of wood and biomass (Shvidenko 2003), as well as regionally for rural development (Pallot and Moran 2000). At the same time there are governance challenges (Nysten-Haarala 2009, Elbakidze et al. 2010). In the Russian Federation, the first Model Forest appeared in 1994 and five Model Forests established a national network in 2006 (Anon. 2008, Elbakidze et al. 2010). According to this "Initiative Network of Russian Model Forests", the Russian Model Forests are long-term projects, which are developed based on generally recognized international and Russian principles of SFM (Anon. 2008, Elbakidze and Angelstam 2008). In addition to the six principles defined by the International Model Forest Network (IMFNS 2008), six new ones were formulated for Russia. These included a focus on solving SFM problems, long-term planning of Model Forest activities (strategic planning for no less than five years with the perspective of 10 to 15 years), practical testing of innovations on the ground, sufficient financial support for imple- mentation of the main tasks of Model Forests, organizational provisions for equality of Model Forest partners, and political support by governmental organizations at the federal and regional levels. At the end of 2007, the Russian Federation's Forestry Agency, inspired by the Model Forest concept, planned to create 31 Model Forests in addition to the five existing at the time (Zheldak 2008). The vision was that the suite of Model Forests should represent all forest zones in the Russian Federation, and would become role models for SFM based on Russian and international experiences (Elbakidze and Angelstam 2008). Given the interest and potential to base regional development on forest resources in Russia (Martynuk et al. 2009), the need for applying integrated landscape approaches, like the Model Forest concept (Axelsson et al. 2008), to support SFM implementation remains an urgent task (World Forestry Congress 2009).

The purpose of this study is to identify stakeholders and their values, needs and interests in the use and management of the forest landscapes of the Kovdozersky Model Forest. In this paper we focus on the rights of stakeholders to use natural resources, the societal sectors represented by different stakeholders, and the spatial extent of stakeholders' activities. Identification and analysis of stakeholders is important for understanding the potential for collaboration among Model Forest stakeholders at multiple levels and, thus, to developing their adaptive capacity and collaborative learning processes to take advantage of opportunities, and handle uncertainties and risks (Daniels and Walker 2001).

\section{Kovdozersky Model Forest}

The Kovdozersky Model Forest is located in the southern part of the Murmansk region $\left(66^{\circ} \mathrm{N}, 32^{\circ} \mathrm{E}\right)$ in the northwest of the Russian Federation (Fig. 1). Geographically, the Kovdozersky Model Forest occupies the lower part of the Kovda River catchment, which has its headwaters on both sides of the Russian-Finnish border and ends in the White Sea. The Model Forest area encompasses the Kovdozersky state forest management unit, a few settlements, many lakes and a small amount of agricultural land. The area of the Model Forest is 400626 ha and it is dominated by Scots pine (Pinus sylvestris L.) in lowland areas and Norway spruce (Picea abies [L.] H. Karst.) at higher elevations.

There are eight settlements in the area of the Model Forest. In several villages, such as Kovda and Zarechensk, local people have maintained their traditional land use practices, which are based on local forest resources. The total number of people living in the area is about 15000 , with a population density of 3.7 people per $\mathrm{km}^{2}$ (Anon. 2003, 2006). A majority of the population lives in the town of Zelenoborskiy. There are also many abandoned logging villages from the previous period of exploitative logging in the area (Elbakidze et al. 2007).

The area began to develop economically during the $15^{\text {th }}$ century when Russians started to settle along the White Sea coast. The main activities were shipbuilding, fishing, fish pickling, reindeer farming and fish barrel production (Beresnev 1987, Elbakidze et al. 2007). In 1890, the first sawmill was built near the mouth of the Kovda River and resulted in a period of intensive wood harvesting and export of high-quality lumber. Two more sawmills were built in 1899 and 1901 . The amount of harvested wood increased after 1915 when another sawmill was built near Kovda Lake to supply timber 


\section{Russia and Northern Europe}

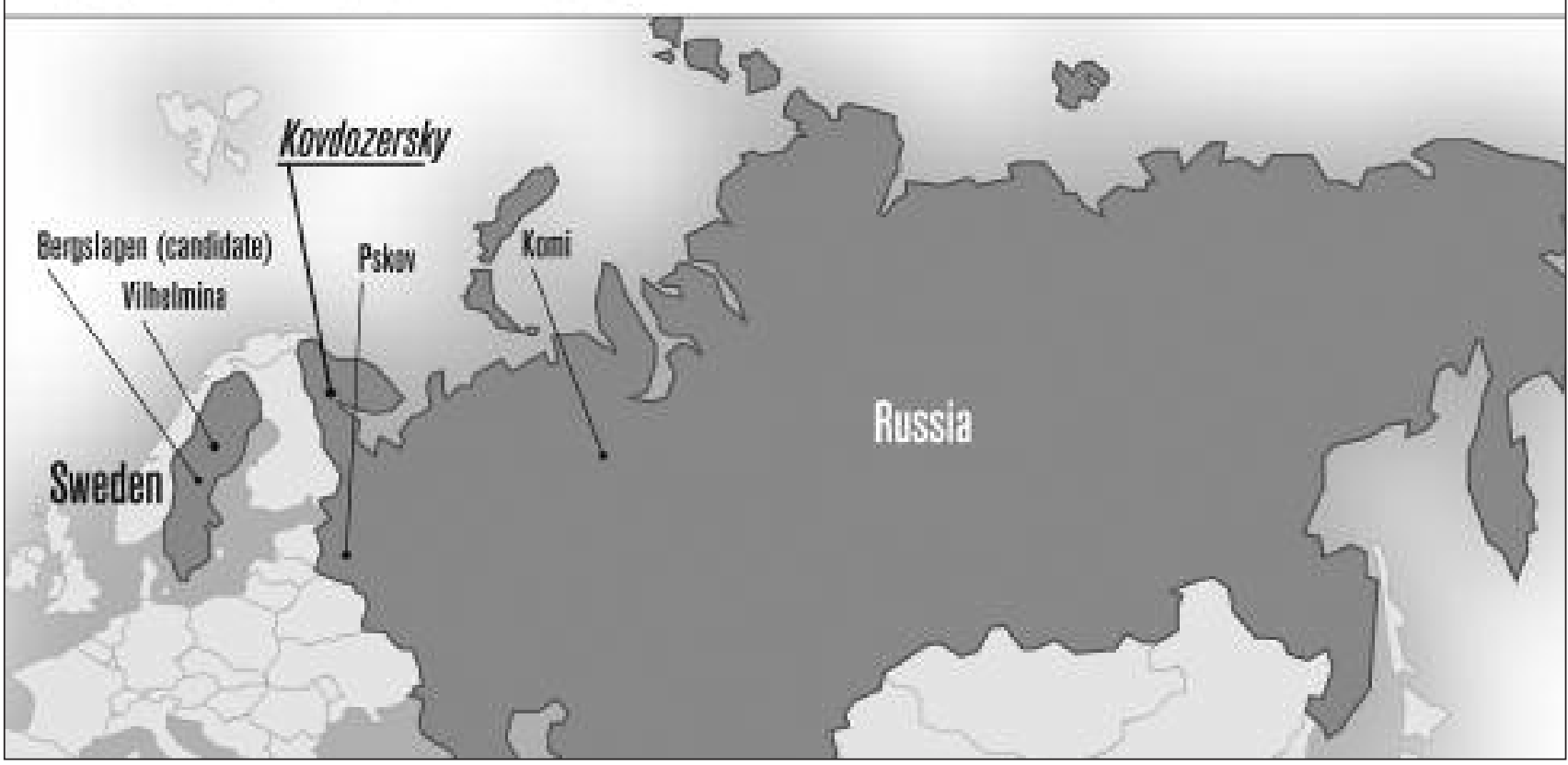

Fig. 1. Location of the Kovdozersky Model Forest, Russian Federation.

for the construction of the railway from Petrozavodsk to Murmansk (Beresnev 1987).

Several new sawmills were built in the 1920s, which produced timber for export. Industrial development of the area increased in the 1950s when the construction of the Kovdozersky hydro-electric power station required construction material for house-building. Two state timber industry enterprises were started in the 1950s (Beresnev 1987) and forestry was the main industry in the area during the Soviet period, especially from the 1950s to the 1980s. Harvesting of oldgrowth boreal forest was very intensive during this period, and annual allowable cuts were often exceeded. This was a result of competition among the state forest enterprises to fulfil or exceed the five-year plans of the socialistic economic development at the time (Elbakidze et al. 2007).

In the early 1990s, the area also suffered from an economic decline and the local forest industry was closed as a result of the reformation of the Russian economy from socialistic planned to market economy. Poor competitiveness of the forest industry owing to its remote location, the previous unsustainable use of the forest resource, and the lack of silviculture all led to the decline of the forest industry (Beresnev 1987, Elbakidze et al. 2007).

During the past decade, ideas concerning sustainable use and restoration of forest landscapes have been discussed among the main forest stakeholders. As a result, a new approach to regional development through the adoption of the Model Forest concept was introduced. Initial support for the development of Kovdozersky Model Forest came from the Barents Regional Council in 2002. In 2003, the Kovdozersky state forest management unit was chosen out of several candidates. At present, the Kovdozersky Model Forest is cooperating with other Model Forests in the Russian Federation to enhance political and financial support for their activities.

\section{Methods and Materials}

To identify the stakeholders of the Kovdozersky Model Forest and their different interests and use of the forest landscape, a total of 36 open-ended qualitative interviews were conducted from 2006 to 2008 with stakeholders of the Model Forest. All interviews were conducted face-to-face and lasted between 60 and 180 minutes. Each was recorded digitally and transcribed. The analysis of interviews was complemented with socio-economic statistical data from the 2003 All-Russian Population Census, archives of local and regional administrations and relevant publications.

All the Model Forest's stakeholders were divided according to three variables. First, according to their rights to use natural resources: (i) stakeholders leasing land from the state for short or long periods to conduct different kinds of activities that had been agreed with the state as a land and forest owner (for example, the Kovdozersky state forest management unit); (ii) forest contractors leasing the forests from the Kovdozersky state forest management unit for periods of up to 49 years; and (iii) forest users who were buying standing wood through auctions. Second, drawing upon Mingione (1991), we defined three groups of stakeholders according to the sector they represented: (i) the civil sector, comprised of a broad range of organizations outside of government, including civil associations, non-profit organizations, churches, and neighbourhood clubs that contributed to the public good (Kingsley and Gibson 1997), (ii) the private sector, made up of businesses controlled or owned by private individuals, directly or through stock ownership, and (iii) the public sector, including stakeholders representing public interests through governmental agencies and local government's units (Elbakidze et al. 2010). Third, we grouped the Model Forest's stakeholders according to the geographical scope of their activities: (i) locally, (ii) regionally, (iii) nationally, and (iv) internationally. 
To make a survey of the products derived from different kinds of natural resources we divided them into use (direct and indirect) and non-use values (Merlo and Croitoru 2005). Direct use values included consumptive (e.g., wood and nonwood goods) as well as non-consumptive direct use values in terms of landscape quality for recreation and tourism. Indirect use values included ecosystem services such as watershed protection, water purification and carbon sequestration. Non-use values were closely linked to conservation interests among landscape stakeholders. Two examples are (1) bequest values arising from placing a value on the conservation of natural or cultural elements of the landscape for future generations, and (2) existence values derived from the knowledge of conserved ecosystems, habitats or species.

The forest landscape of the Kovdozersky Model Forest was also stratified into five components to capture the landscape diversity found in the region: (i) the air mass, (ii) the open land, (iii) the forested land, (iv) the water (rivers and lakes), and (v) the ground (quaternary deposits, bedrock and groundwater).

\section{Results}

\section{Stakeholders within the Model Forest}

In total we identified 31 stakeholders operating in the area of the Kovdozersky Model Forest, including 13 land leasers, 9 forest contractors, 6 forest users, and 3 potential forest contractors whose rights to use forests were under negotiation with the state. Stakeholders from all societal sectors-civil, private, and public - used landscape goods, services and values to create products through different activities. However, the main group of stakeholders was from the private sector (55\%). The representatives of the private sector were mainly small-scale forest logging companies, tourist enterprises and an agricultural company. The smallest stakeholder group represented the civil sector and included only one organization, the local gardening society. Stakeholders from the public sector included the Kovdozersky state forest management unit, the state-owned hydro-electric company, and the administrations of the state protected areas. A diverse set of interests and business opportunities were represented, including smallscale forest industry based on local forest resources, tourism (nature-based, sport, fishing and hunting), maintenance and restoration of fish population, small-scale farming and fisheries, and construction of district heating systems.

Stakeholders used landscape goods, services and values in different ways (Table 1). Stakeholders with direct use of natural resources were from public and private sectors concerned with the extraction of natural resources including wood, fish and game, as well as the use of river power to produce electricity by the establishment of several large water reservoirs and power stations. These stakeholders had the most substantial impact on the physical landscape. Additionally, sport hunting for grouse-(capercaillie [Tetrao urogallus L.], black grouse [Tetrao tetrix L.], hazel grouse [Tetrastes bonasia L.])ducks (Anatidae spp.) and moose (Alces alces L.) was the objective of several stakeholders. In the interviews, stakeholders expressed their concern that intensive hunting could affect game population size and productivity. They concluded there was a need for game management to assure that hunting can continue, as well as to identify areas with suitable habitat for different species.

Stakeholders representing the local forest industry were faced with many challenges related to business development. After a 50-year history of intensive wood harvesting amount-

Table 1. Use of landscape goods, services and values in the area of Kovdozersky Model Forest

\begin{tabular}{|c|c|c|c|c|c|}
\hline \multirow[b]{3}{*}{ Landscape strata } & \multicolumn{3}{|c|}{ Use values } & \multirow{2}{*}{\multicolumn{2}{|c|}{ Non-use values }} \\
\hline & \multicolumn{2}{|c|}{ Direct use values } & \multirow{2}{*}{$\begin{array}{c}\text { Indirect use values } \\
\text { Services }\end{array}$} & & \\
\hline & Consumptive values & $\begin{array}{l}\text { Non consumptive } \\
\text { values }\end{array}$ & & Bequest values & Existence values \\
\hline Air mass & & $\begin{array}{l}\text { Recreation } \\
\text { Tourism }\end{array}$ & $\begin{array}{l}\text { Air quality } \\
\text { Climate }\end{array}$ & Landscape beauty & \\
\hline Open land & $\begin{array}{l}\text { Agriculture } \\
\text { Hunting }\end{array}$ & $\begin{array}{l}\text { Tourism } \\
\text { Recreation }\end{array}$ & & Cultural heritage & \\
\hline Forest & $\begin{array}{l}\text { Forestry } \\
\text { Hunting } \\
\text { Land exploitation }\end{array}$ & $\begin{array}{l}\text { Recreation } \\
\text { Tourism }\end{array}$ & $\begin{array}{l}\text { Water quality } \\
\text { Air quality } \\
\text { Climate } \\
\text { Watershed protection }\end{array}$ & $\begin{array}{l}\text { Biodiversity } \\
\text { Nature conservation }\end{array}$ & $\begin{array}{l}\text { Biodiversity } \\
\text { Nature conservation }\end{array}$ \\
\hline Water & $\begin{array}{l}\text { Fishing } \\
\text { Hydro-electric }\end{array}$ & $\begin{array}{l}\text { Fish production } \\
\text { Recreation } \\
\text { Tourism }\end{array}$ & $\begin{array}{l}\text { Kinetic energy } \\
\text { Natural disturbance } \\
\text { regimes } \\
\text { Water quality }\end{array}$ & $\begin{array}{l}\text { Biodiversity } \\
\text { Cultural heritage } \\
\text { Nature conservation }\end{array}$ & $\begin{array}{l}\text { Biodiversity } \\
\text { Nature conservation }\end{array}$ \\
\hline Ground & $\begin{array}{l}\text { Ground water } \\
\text { Mining } \\
\text { Sand/gravel pits }\end{array}$ & Mineral prospecting & Water purification & Nature conservation & \\
\hline
\end{tabular}


ing to $700000 \mathrm{~m}^{3}$ per year in the 1980s, the present annual harvest had decreased to about $10000 \mathrm{~m}^{3}$ (Elbakidze et al. 2007). According to the state forest management plan, about $100000 \mathrm{~m}^{3}$ can be harvested annually, although mainly in areas located far away from any transport infrastructure-an illustration of the problem with inaccessibility of large parts of the forests for harvesting (Filiushkina 2006). As a driving force to introduce intensive forest management, there have been discussions among stakeholders from private and public sectors to build district heating facilities that could use wood chips from smaller-diameter timber harvested during thinning operations.

Another group of stakeholders included private businesses providing recreation and tourism services. These stakeholders' use of the natural resources was mainly non-consumptive, although consumptive use of non-wood goods was involved in some cases. For example, wilderness tourism had been established successfully and the area being used for these tours was large. It included long-distance river trips, and snowmobile safaris from Finland to the White Sea, thus traversing the Kovdozersky Model Forest.

Non-use values of the landscape were of importance to a smaller number of stakeholders. These included existence values, which were closely linked to nature conservation interests, and bequest values that encompassed cultural heritage conservation interests. At the time of our study, culture tourism was starting to emerge as the region has a long history of human settlement and use. The final group of stakeholders included groups formed by authorities with control functions. While these stakeholders did not use the natural resources actively, they played an important role in law enforcement and implementation of natural resource policies. The administration of the Kovdozersky forest management unit, local administration, railroad and road authorities were some examples of stakeholders in this group.

\section{Spatial extent of forest landscape use}

Stakeholders focused their business activities based on use of ecosystems services, across a wide spatial scale, from local to international. However, almost 50\% of all stakeholders con-

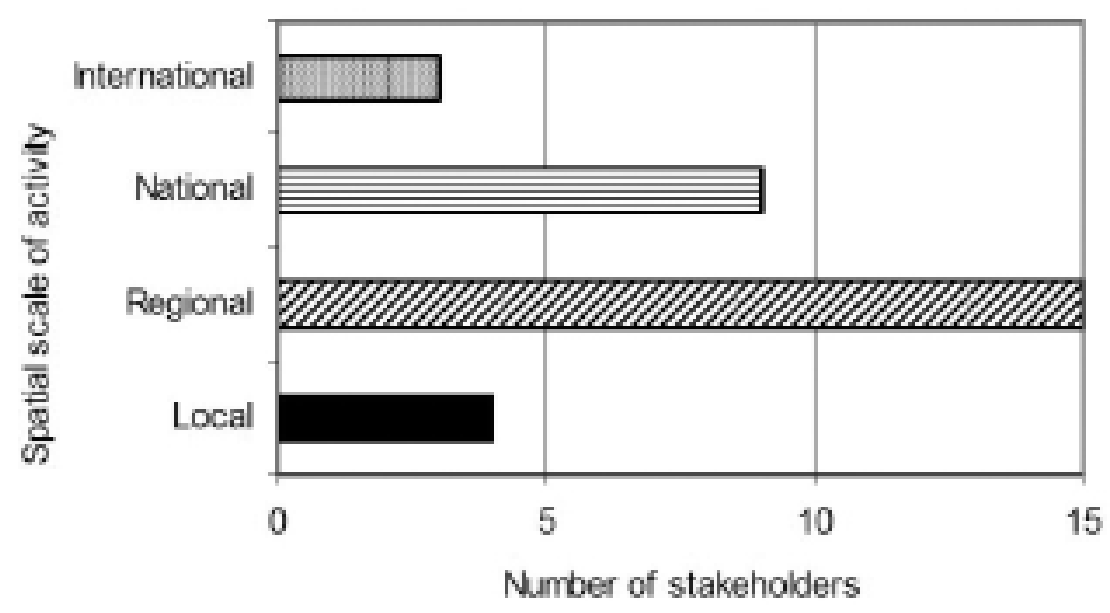

Fig. 2. Distribution of stakeholders' business activities based on consumption of landscape's goods, services and values as well as ecosystem services in the Kovdozersky Model Forest. centrated their activities within the Murmansk region (Fig. 2). Based on interviews, we found that four spatial scales of stakeholder activities need to be considered in different types of spatial planning (Table 2). The main planning unit was the Kovdozersky forest management unit. An important task was to support the co-existence of forest land leasers operating at different spatial scales with planning for multiple uses within and among lease areas. A total of 17 stakeholders leased parts of this management unit for wood harvesting, hunting and recreation. Three land users also had a need for regional planning at the scale of the entire Kovda River catchment, including hydro-electric power production, conservation of intact old-growth forest areas in Fennoscandia, and tourism linked to the Finnish and Russian cultural heritage in the border region.

\section{Discussion}

Stakeholder identification for spatial planning and adaptive governance

Our study shows that demand for the natural resources within the Kovdozersky Model Forest was diverse. However, so far there has not been any severe competition among stakeholders related to the use of goods, services and values. Nevertheless, the increasing number of stakeholders operating in the area could lead to negative externalities of economic use of natural resources, maintenance of the landscape's ecological and cultural values and risks for conflicts among different stakeholders. To secure sustainable use of the forest landscape's goods, services and values, their spatial distribution needs to be mapped and communicated among stakeholders. In addition, different stakeholders need to learn about each other's use of the forest landscape. For example, an assessment of wood resources for timber and bio-fuel, habitat suitability for game and fish, resources for nature and culture tourism development, and nature conservation is needed.

To develop adaptive governance of the Kovdozersky Model Forest there is a need to: (1) monitor and visualise the state and trends of ecological, economic and social cultural dimensions of landscape sustainability and to relate this to the present use of landscape goods, services and values by different stakeholders, (2) use the Kovdozersky Model Forest as a platform where stakeholders can collaborate on the future management of natural resources based on principles of sustainable development, and (3) perform multiplescale spatial planning to reconcile the needs and interests of different stakeholders and their use of landscape goods, services and values. However, the activities developed by participants in the Kovdozersky Model Forest did not reflect the values and needs of all stakeholders (Elbakidze et al. 2007). The main goal of the Kovdozersky Model Forest was to develop and restore 
Table 2. Spatial scales for different types of planning identified from interviews with stakeholders using landscape goods, services and values in the Kovdozersky Model Forest

\begin{tabular}{|c|c|c|}
\hline Spatial scale & Type of planning & Landscape stakeholders \\
\hline $\begin{array}{l}\text { Trees in stands } \\
(\sim 1-100 \text { ha })\end{array}$ & $\begin{array}{l}\text { Operational planning (e.g., general } \\
\text { considerations in forest management, } \\
\text { stream and riparian management) }\end{array}$ & Forest leasers that harvest wood \\
\hline $\begin{array}{l}\text { Stands in management sub-unit } \\
\text { (e.g., leasing area) } \\
(\sim 2000 \text { to } 100000 \mathrm{ha})\end{array}$ & $\begin{array}{l}\text { Tactical planning (e.g., forest management, } \\
\text { landscape planning for game species) }\end{array}$ & $\begin{array}{l}\text { Kovdozersky state forest management unit, } \\
\text { nature protection units }\end{array}$ \\
\hline $\begin{array}{l}\text { Landscapes in a management unit } \\
(\sim 500000 \text { ha })\end{array}$ & $\begin{array}{l}\text { Strategic planning in the Kovdozersky } \\
\text { Model Forest (e.g., to assure co-existence } \\
\text { of use of wood, non-wood goods, energy, } \\
\text { tourism) }\end{array}$ & $\begin{array}{l}\text { Kovdozersky state forest management unit, } \\
\text { hunting enterprises }\end{array}$ \\
\hline $\begin{array}{l}\text { River catchment in the boreal forest } \\
(\sim 5000000 \text { ha })\end{array}$ & $\begin{array}{l}\text { Regional planning for sustainable } \\
\text { development (e.g., hydro power, tourism, } \\
\text { conservation of "green belt" forest) }\end{array}$ & $\begin{array}{l}\text { Hydro-electricity production, authorities } \\
\text { working with nature conservation, tourism } \\
\text { enterprises }\end{array}$ \\
\hline
\end{tabular}

the forest industry in the region. However, forestry and the forest industry were not profitable in the area during the Soviet era. The dominance of industrial forestry issues in the Model Forest's activities was a result of the domination of industrial representatives in the decision-making process (Elbakidze et al. 2007). Because of the limited possibility for industrial forestry development, this issue needs to be further discussed among stakeholders. However, this requires moving higher on the ladder of participation (Arnstein 1969), i.e., to learn how to collaborate and further develop the partnership to reflect the stakeholders' interests, needs and values. One option is to orientate the Model Forest's activities towards exploring both industrial and non-industrial use of forest resources and services, including, but not limited to, tourism based on nature and cultural heritage in the area. SFM therefore becomes a matter of sustainable landscapes, and the need to encompass both social and ecological systems (Dietz et al. 2003, Lazdinis and Angelstam 2004, Folke et al. 2005, Alxesson et al. 2008, 2011).

The Model Forest concept is an example of a "soft law" in the Russian Federation (Elbakidze and Angelstam 2008), thus providing an official mandate supporting innovations in the field of SFM policy implementation. Application of the Model Forest concept could be a very useful tool during the period of decentralisation of the forest sector in Russia as stated in the present Forest Code. Further development of a national Model Forest network could be seen as a window of opportunity to develop adaptive forest governance systems instead of the current bureaucratic top-down government system in the forest sector, with a huge gap in the decision-making process between the needs and interests of forest stakeholders at the local level, and policy-makers at the top level (Zheldak 2008, Kuz'minov 2009, Martynuk et al. 2009).

There are many challenges related to the establishment of a Model Forest and its usefulness in the Russian Federation to issues related to the implementation of sustainable management and sustainability of forest landscapes. For example, because forest land is state-owned in Russia, Model Forests are usually located primarily on the area of state forest enterprises. Their main activity is often directed at radical improvement of the situation in the wood-based forest sector, an important goal considering the past and current status of the forest industry in the region. However, issues such as rural development, multiple use of forests, development of transport infrastructure to access wood resources, and its impact on sustainability of forest landscapes are often not included in activity programs (Elbakidze and Angelstam 2008). A traditional narrow forest sector approach is a barrier to the sustainable development of forest landscapes as integrated socioecological systems.

\section{Model Forests as a platform for multi-stakeholder collaboration in the Barents Region}

The Barents Region, where the Kovdozersky Model Forest is located, offers an opportunity for novel neighbourhood collaboration and learning concerning land use issues, including nature conservation, forestry, mining, rural development, how to handle environmental issues and energy as well as education. The importance of northern forests from environmental, economic, social and cultural perspectives has been recognised globally (Carlson et al. 2009). The conservation and sustainable use of forest landscapes in general requires integrated land use planning based on multi-level collaboration among different societal sectors at multiple levels from local to international (Ostrom 1990, Bellamy and Johnson 2000). Model Forests could be seen as an appropriate platform for multi-stakeholder collaboration toward integrated land use planning (Besseau et al. 2002, Elbakidze et al. 2010). In northwestern Russia, a key issue is poorly developed forest management and planning that indirectly leads to continued harvesting of Europe's last intact, natural forests (Burton et al. 2003). Rural areas, especially in remote regions like the Kovdozersky Model Forest, also face significant problems regarding economic growth, development and job opportunities. This is linked to deterioration of cultural and social capital due to depopulation and isolation of remote areas as well as rural-to-urban migration and individualisation of society (Lehtinen et al. 2004).

Implementation of the vision of sustainable use of forest landscapes' natural resources in the Barents Regions, includ- 
ing the Kovdozersky Model Forest, requires integration of conservation, forest management, industrial and rural development by integrated land use planning of landscapes and regions. This implies the use of a zoning approach with zones for: (1) conservation of natural ecosystems' composition, structure and function to secure ecosystem services, (2) intensive forest management, and (3) multiple use of forest landscapes. Such planning must be adapted to the biophysical and societal contexts of the different parts of the Barents Region. It will also be important to include educational organisations as they play a vital role for future governance and management (County Administrative Board of Norrbotten 2011). As stated at the World Forestry Congress (2009): "The path forward lies in shifting to an integrated landscape approach, working with partners outside the forest sector to develop sustainable multi-sector responses". Identifying not just the stakeholders but also their values, needs and interests is critical in the development and implementation of adaptive governance for the sustainable management of large landscapes.

\section{Acknowledgements}

Preparation of this manuscript was funded by FORMAS, Marcus and Amalia Wallenbergs Minnesfond and the Swedish Ministry of Environment. Most of the data collection took place as a part of the EU BSR INTERREG project Baltic Forest. We thank the partners and other interviewees in the Kovdozersky Model Forest for their time and valuable contributions.

\section{References}

Angelstam, P. and M. Elbakidze. 2010. Human ecological footprints on forests at multiple spatial scales: toward learning for sustainability and integrated landscape management using Europe as a laboratory. In A. Hornborg and A. Jorgensen (eds.). International Trade and Environmental Justice: Toward a Global Political Ecology. pp. 147-173. Nova Science Publishers Inc., New York.

Anon. 1995. Pan-European Criteria and Indicators for Sustainable Forest Management. Annex 1 of the Resolution 1, Lisbon. Vienna Liaison Unit.

Anon. 1998. The Resolution L2 Pan-European Criteria and Indicators for Sustainable Forest Management. Third Ministerial Conference on the Protection of Forests in Europe. 2-4 June 1998, Lisbon, Portugal.

Anon. 2001. Criteria and indicators for sustainable forest management of the MCPFE. International expert meeting on monitoring, assessment and reporting on the progress towards Sustainable Forest Management 5-8 November 2001, Yokohama, Japan.

Anon. 2003. All-Russian Population Census. Federal Service of the State Statistic 2002.

Anon. 2006. Archives of the Zelenoborsk Municipal Administration in Murmansk Oblast.

Anon. 2007. State of Europe's Forests 2007. The MCPFE report on sustainable forest management in Europe. Ministerial Conference on the Protection of Forests in Europe, Liaison Unit, Warsaw.

Anon. 2008. The concept of Russian Model Forest network. Ustoychivoe lesopolzovanie, WWF 2 (18): 18-25 (In Russian).

Arnstein, S. 1969. A ladder of citizen participation. Journal of the American Institute of Planners 35: 216-224.

Axelsson, R., P. Angelstam and M. Elbakidze. 2008. Landscape approaches to sustainability. In B. Frostell, A. Danielsson, L. Hagberg, B.-O. Linnér and E. Lisberg Jensen. (eds.). Science for sustainable development - The social challenge with emphasis on the conditions for change. pp. 169-177. VHU, Uppsala, Sweden.
Axelsson, R., Angelstam, P., Elbakidze, M., Stryamets, N., Johansson, K.-E. 2011. Sustainable development and sustainability: Landscape approach as a practical interpretation of principles and implementation concepts. Journal of Landscape Ecology 4(3):5-30

Bellamy, J. A. and A. K. L. Johnson. 2000. Integrated resource management: moving from rhetoric to practice in Australian agriculture. Envir. Manag. 25(3): 265-80.

Beresnev, N. 1987. Knyazaya guba. Murmansk, Russia. 58 p. (In Russian)

Besseau, P., K. Dansou and F. Johnson. 2002. The international model forest network (IMFN): elements of success. For. Chron. 7: 648-654.

Blomquist, W. 1992. Dividing the waters: governing groundwater in Southern California. ICS Press, San Francisco. 415p.

Burton, P. J., C. Messier, D.W. Smith and W.L. Adamowicz (eds.). 2003. Towards sustainable management of the boreal forest. NRC Research Press, Ottawa. 1039 p.

Carlson, M., J. Wells and D. Roberts. 2009. The carbon the world forgot: conserving the capacity of Canada's boreal forests region to mitigate and adapt to climate change. Boreal Songbird Initiative and Canadian Boreal Initiative, Seattle, WA, and Ottawa. 33 p.

County Administrative Board of Norrbotten. 2011. Our Barents our future. Towards a civil, economical and environmental wellbeing in Barents - securing a sustainable use of human and natural resources. County Administrative Board of Norrbotten, Luleå.

Daniels, S.E. and G.B. Walker. 2001. Working through environmental conflict - the collaborative learning approach. Praeger, Westport and London.

Dietz, T., E. Ostrom and P.C. Stern. 2003. The struggle to govern the commons. Science 302: 1902-1912.

Elbakidze, M. and P. Angelstam. 2008. Model Forests in the Russian Federation's northwest: a view from the outside. Ystoychivoe lesopolzovamie 17(1): 39-47 (In Russian).

Elbakidze, M., P. Angelstam and R. Axelsson. 2007. Sustainable forest management as an approach to regional development in the Russian Federation: state and trends in Kovdozersky Model Forest in the Barents region. Sc. J. For. Res. 22: 568-581.

Elbakidze, M., P. Angelstam, C. Sandström and R. Axelsson. 2010. Multi-stakeholder collaboration in Russian and Swedish Model Forest initiatives: adaptive governance towards sustainable forest landscapes? Ecol. Society 15(2): 14. [online] Available from http://www.ecologyandsociety.org/vol15/iss2/art14/.

Filiushkina, G. 2006. Economic organisation of forest use under long-term lease of forest fund. VNIILM, Pushkino. 172 p. (In Russian).

Folke, C., T. Hahn, P. Olsson and J. Norberg. 2005. Adaptive governance of social-ecological knowledge. Ann. Rev. Envir. Resources 30: 441-473.

Healey, P. 1996. The communicative turn in planning theory and its implications for spatial strategy formation. Environment and Planning B: Planning and Design 23: 217-234.

[IMFNS] International Model Forest Network Secretariat. 2008. Model Forest development guide. Natural Resources Canada, Canadian Forest Service, Ottawa.

Kingsley, G.H. and J. Gibson. 1997. Civil society, the public sector, and poor communities. No. 12 Paper in Series. The Future of the Public Sector. The Urban Institute, Washington, DC.

Kuz'minov, I. 2009. Model Forests: the history and themes of the projects. Ystoychivoe lesopolzovanie WWF 3 (22): 45-49. (In Russian).

LaPierre, L. 2002. Canada's Model Forest program. For. Chron. 78: 613-617.

Lazdinis, M. and P. Angelstam. 2004. Connecting social and ecological systems: an integrated toolbox for hierarchical evaluation of biodiversity policy implementation. Ecol. Bull. 51: 385-400.

Lehtinen, A., J. Donner-Amnell and B. Sæther (eds.). 2004. Politics of forests - northern forest-industrial regimes in the age of globalization. Ashgate Publishing, Hants, UK. 287 p. 
Martynuk, A., V. Sidorenkov and V. Zheldak. 2009. Scieitific and methodolodical framework for creation and development of Model Forests in Russia. Ustoychivoe lesopolzovanie WWF 2 (18): 9-11. (In Russian).

Merlo, M. and L. Croitoru. 2005. Concepts and methodology: a first attempt towards quantification. In M. Merlo and L. Croitoru (eds.). Valuing Mediterranean forests. Towards total economic value. pp. 17-36. CABI Publishing.

Mingione, E. 1991. Fragmented societies. The sociology of economic life beyond the market paradigm. Basil Blackwell, Oxford. $74 \mathrm{p}$.

Nysten-Haarala, S. 2009. The changing governance of renewable natural resources in Northwest Russia. Ashgate, Farnham, UK.

Ostrom, E. 1990. Governing the commons: The evolution of institutions for collective action. Cambridge Univ. Press, New York.

Pallot, J. and D. Moran. 2000. Surviving the margins in Post-Soviet Russia: Forestry villages in Northern Perm' Oblast. Post-Soviet Geography and Economics 42(5): 199-213.

Potapov, P. et al. 2008. Mapping the world's intact forest landscapes by remote sensing. Ecol. Society 13(2): 51. [online] Available from http://www.ecologyandsociety.org/vol13/iss2/art51/
Shindler, B.A., T.M. Finlay and M.C. Beckley (eds.). 2003. Two paths toward sustainable forests. Public values in Canada and the United States. Oregon State University Press, Corvallis, OR.

Shvidenko A. 2003. Russian forests at the beginning of the third millennium: Status and trends. Proceedings of the XII World Forestry Congress, September 21 to 28, 2003, Quebec, Canada, Series B - forests for the planet, 27-34

Shvidenko, A, and S. Nilsson. 2002. Dynamics of Russian Forests and the Carbon Budget in 1961-1998: An Assessment Based on Long-Term Forest Inventory Data. Climatic Change 55(1-2): 5-37. Thomas, C.W. 2003. Bureaucratic Landscapes: Interagency Cooperation and the Preservation of Biodiversity. MA MIT Press, Cambridge, UK. 352 p.

Zheldak, V. 2008. Development of Model Forest in Russia. Ustoychivoe lesopolzovanie WWF 2 (18): 12-17. (In Russian).

World Forestry Congress. 2009. Forest Development: A Vital Balance, Findings and Strategic Actions. Findings and Strategic Actions. Available from http://foris.fao.org/meetings/download/_2009/ xiii_th_world_forestry_congress/misc_documents/wfc_declaration.pdf. 